\title{
LETTER
}

\section{Species-specific responses to atmospheric carbon dioxide and tropospheric ozone mediate changes in soil carbon}

Alan F. Talhelm, ${ }^{1 *}$ Kurt S.
Pregitzer ${ }^{1}$ and Donald R. Zak ${ }^{2,3}$
${ }^{1}$ Department of Natural
Resources and Environmental
Science, University of Nevada,
Reno, NV 89512, USA
${ }^{2}$ School of Natural Resources \&
Environment, University of
Michigan, Ann Arbor, MI 48109,
USA
${ }^{3}$ Department of Ecology and
Evolutionary Biology, University
of Michigan, Ann Arbor, MI
48109, USA
*Correspondence: E-mail:
atalhelm@cabnr.unr.edu

Alan F. Talhelm, ${ }^{1 *}$ Kurt S. Pregitzer ${ }^{1}$ and Donald R. Zak ${ }^{2,3}$ ${ }^{1}$ Department of Natural Resources and Environmental Science, University of Nevada, Reno, NV 89512, USA ${ }^{2}$ School of Natural Resources \& Environment, University of Michigan, Ann Arbor, MI 48109, USA

${ }^{3}$ Department of Ecology and Evolutionary Biology, University of Michigan, Ann Arbor, MI 48109, USA atalhelm@cabnr.unr.edu

\begin{abstract}
We repeatedly sampled the surface mineral soil $(0-20 \mathrm{~cm}$ depth) in three northern temperate forest communities over an 11-year experimental fumigation to understand the effects of elevated carbon dioxide $\left(\mathrm{CO}_{2}\right)$ and/or elevated phyto-toxic ozone $\left(\mathrm{O}_{3}\right)$ on soil carbon (C). After 11 years, there was no significant main effect of $\mathrm{CO}_{2}$ or $\mathrm{O}_{3}$ on soil C. However, within the community containing only aspen (Populus tremuloides Michx.), elevated $\mathrm{CO}_{2}$ caused a significant decrease in soil $\mathrm{C}$ content. Together with the observations of increased litter inputs, this result strongly suggests accelerated decomposition under elevated $\mathrm{CO}_{2}$. In addition, an initial reduction in the formation of new (fumigation-derived) soil $\mathrm{C}$ by $\mathrm{O}_{3}$ under elevated $\mathrm{CO}_{2}$ proved to be only a temporary effect, mirroring trends in fine root biomass. Our results contradict predictions of increased soil $\mathrm{C}$ under elevated $\mathrm{CO}_{2}$ and decreased soil $\mathrm{C}$ under elevated $\mathrm{O}_{3}$ and should be considered in models simulating the effects of Earth's altered atmosphere.
\end{abstract}

\section{Keywords}

${ }^{13} \mathrm{C}$, aspen, carbon storage, decomposition, global change, long-term, northern temperate forests.

Ecology Letters (2009) 12: 1219-1228

\section{INTRODUCTION}

One of the uncertainties in modelling the Earth's future climate is predicting the rate at which terrestrial ecosystems will sequester carbon (C) as the composition of the atmosphere changes (IPCC 2007). It is expected that higher concentrations of atmospheric carbon dioxide $\left(\mathrm{CO}_{2}\right)$ will lead to an increase in $\mathrm{C}$ sequestration by stimulating plant growth and net primary productivity (NPP; Ainsworth \& Long 2005). This stimulation of $C$ sequestration includes enhanced belowground growth (de Graaff et al. 2006) and an expected enhancement of $\mathrm{C}$ storage in the soil. These predictions have largely held in the forest free-air elevated $\mathrm{CO}_{2}$ experiments (e.g. Jastrow et al. 2005; Lichter et al. 2005; Hoosbeek et al. 2006) and a meta-analysis suggests that the increase in soil $\mathrm{C}$ outweighs the $\mathrm{CO}_{2}$ stimulation of plant productivity (Luo et al. 2006). However, in many regions, the future atmosphere is also expected to contain increased concentrations of phyto-toxic ozone $\left(\mathrm{O}_{3}\right.$; Dentener et al. 2006), which could reduce soil C storage via reductions in plant growth and belowground C allocation (Grantz et al. 2006). There are few multi-year studies of $\mathrm{O}_{3}$ effects on soil C. Some recent models suggest that the largest changes in terrestrial $\mathrm{C}$ storage from $\mathrm{O}_{3}$ exposure occur through reductions in soil C (Ren et al. 2007; Sitch et al. 2007).

In addition to the direct physiological effects, exposure to increased levels of $\mathrm{CO}_{2}$ or $\mathrm{O}_{3}$ can alter competitive interactions and change dominance hierarchies (Poorter \& Navas 2003; Kubiske et al. 2007; Zak et al. 2007). Physiological differences among the genotypes or species within a community mean that these modified communities can exhibit productivity responses to altered atmospheric composition that are either stronger or weaker than those found in the original community (Bradley \& Pregitzer 2007).

Very few studies have examined long-term belowground responses of forest ecosystems to $\mathrm{CO}_{2}$ and $\mathrm{O}_{3}$ (Kasurinen et al. 2004). The Rhinelander FACE (free-air $\mathrm{CO}_{2}$ enrichment) experiment is currently the only FACE experiment that examines the responses of forest communities exposed to elevated $\mathrm{CO}_{2}\left(+\mathrm{CO}_{2}\right)$, elevated $\mathrm{O}_{3}\left(+\mathrm{O}_{3}\right)$ and both 
elevated $\mathrm{CO}_{2}$ and elevated $\mathrm{O}_{3}\left(+\mathrm{CO}_{2}+\mathrm{O}_{3}\right)$. One early finding of the Rhinelander FACE experiment was that the pool of new soil $\mathrm{C}$ in the $+\mathrm{CO}_{2}+\mathrm{O}_{3}$ treatment was significantly lower than that under $+\mathrm{CO}_{2}$ alone (Loya et al. 2003). A significant $\mathrm{CO}_{2} \times \mathrm{O}_{3} \times$ time interaction affecting belowground processes (e.g. soil respiration, fine root production) has occurred at both Rhinelander FACE (Pregitzer et al. 2008) and in a multi-year chamber experiment (Kasurinen et al. 2004). However, there is no research to date on whether such a $\mathrm{CO}_{2} \times \mathrm{O}_{3} \times$ time interaction also affects soil C dynamics. Consequently, it was unknown whether the initial reduction in new soil $\mathrm{C}$ content by $\mathrm{O}_{3}$ under elevated $\mathrm{CO}_{2}$ at Rhinelander FACE would persist in the long-term. Effects of the treatments on other factors that can influence soil C cycling such as NPP (King et al. 2005), community composition (Kubiske et al. 2007) and decomposition (Chapman et al. 2005; Parsons et al. 2008) also suggested a need to reexamine soil $\mathrm{C}$ pools.

Our predictions for surface mineral soil $\mathrm{C}$ were that (1) soil $\mathrm{C}$ pools would be greater under elevated $\mathrm{CO}_{2}$ than under ambient $\mathrm{CO}_{2}$ and that (2) elevated $\mathrm{O}_{3}$ would decrease soil $\mathrm{C}$ pools relative to ambient $\mathrm{O}_{3}$, regardless of the fumigation level of $\mathrm{CO}_{2}$. In addition, we expected that (3) elevated $\mathrm{CO}_{2}\left(+\mathrm{CO}_{2}\right)$ would create a larger pool of new soil $\mathrm{C}$ than a combination of elevated $\mathrm{CO}_{2}$ and elevated $\mathrm{O}_{3}$ $\left(+\mathrm{CO}_{2}+\mathrm{O}_{3}\right)$. At Rhinelander FACE, the treatment gases have largely had the predicted effects on leaf litter production. However, the shifts in species composition (Kubiske et al. 2007) and the transient response of fine roots and soil respiration (Pregitzer et al. 2008) in the two elevated $\mathrm{O}_{3}$ treatments $\left(+\mathrm{O}_{3},+\mathrm{CO}_{2}+\mathrm{O}_{3}\right)$ may have influenced mineral soil $\mathrm{C}$ through time. The first objective of this report was to determine if changes in surface mineral soil $\mathrm{C}$ were consistent with the initially predicted treatment effects. The second objective was to understand how these dynamics have influenced the proportion of new soil $\mathrm{C}$, i.e. $\mathrm{C}$ fixed during the 11 years of fumigation.

\section{MATERIALS AND METHODS}

The FACE experiment in Rhinelander, Wisconsin, USA $\left(45^{\circ} 40.5^{\prime} \mathrm{N}, 89^{\circ} 37.5^{\prime} \mathrm{W}, 490\right.$ m.a.s.l.) consists of twelve 30-m diameter rings, arranged in three randomized complete blocks (Karnosky et al. 2005). Treatments consisted of factorial $\mathrm{CO}_{2}$ and $\mathrm{O}_{3}$ fumigation, composed of ambient and elevated levels of each trace gas; these treatments were randomly assigned within each block. Fumigation began in 1998 and occurred during the daylight hours of the growing season. Annual concentrations during fumigation are c. $50-55 \mathrm{~nL} \mathrm{~L}^{-1}$ for elevated $\mathrm{O}_{3}$ and $520-525 \mu \mathrm{L} \mathrm{L}^{-1}$ for elevated $\mathrm{CO}_{2}$ (Kubiske et al. 2007). The source $\mathrm{CO}_{2}$ used to create the elevated $\mathrm{CO}_{2}$ treatment was fossil-fuel-derived and highly depleted in ${ }^{13} \mathrm{C}(-43.7 \% \pm 0.2$; Pregitzer et al.
2006). Soils at the site are Alfic Haplorthods (Pandus series) with a sandy loam Ap horizon overlaying a sandy clay loam $\mathrm{Bt}$ horizon. Historical use of the site was predominantly agricultural, but the site was planted with trees in 1972. These trees were cut prior to establishment of the experiment; stumps were removed and the soils were disked. More detailed description of the soils, experimental design, fumigation technique and fumigation performance can be found in Karnosky et al. (2005).

Small trees $(<25 \mathrm{~cm}$ tall) initiated from potted stock were planted in the rings during July 1997. Half of each ring was planted at 1-m $\times 1-\mathrm{m}$ intervals with five different aspen (Populus tremuloides Michx.) genotypes (Karnosky et al. 2005). The remaining two quarters of each FACE ring were mixed communities planted with either paper birch (Betula papyrifera Marsh) or sugar maple (Acer saccharum Marsh) at equal densities with a single aspen genotype at $1-\mathrm{m} \times 1-\mathrm{m}$ spacing.

\section{Sampling}

Sampling involved the collection of three distinct ecosystem components: surface mineral soil for the determination of both total $\mathrm{C}$ and new $\mathrm{C}$, and fine roots and leaf litter to use as components of the ${ }^{13} \mathrm{C}$ model to determine new C. Soil samples were collected in 1997, 1999, 2001 and annually from 2003 to 2008. In 1999, 2001, 2003-2006 and 2008, five soil cores ( $4.8 \mathrm{~cm}$ diameter) were collected from each community within each FACE ring (15 cores per ring). In 2007, three cores were collected from each community in each ring. After collection, the cores were composited by the community. All of the soil samples were removed from the Ap horizon.

In 1997, the soil was sampled to a depth of $30 \mathrm{~cm}$; in all other years, sampling was to a depth of $20 \mathrm{~cm}$. Sampling in 1997 pre-dated the soil disking and the planting of the three community types, so there is no differentiation by community type in the data presented for that year. As a result of these differences and the difference in sampling depth, we do not directly compare soil $\mathrm{C}$ content and concentrations in 1997 with samples collected after the initiation of the experiment. However, we did use the 1997 data as starting points in the ${ }^{13} \mathrm{C}$ mixing model.

From 2003 to 2008, the soil samples were sieved and hand-sorted to remove roots and coarse fragments (organic material, rocks). Roots were subsequently sorted by size class and herbaceous and dead roots were removed. The soil was then placed in a $65^{\circ} \mathrm{C}$ oven for at least $48 \mathrm{~h}$, and later ground for analysis. The sorted roots were rinsed and placed in a $65^{\circ} \mathrm{C}$ oven for at least $48 \mathrm{~h}$. The root samples were then ground for analysis. Processing in 1999 and 2001 differed from sampling in the other years. In 1999, the roots were extracted from the soil by elutriation of the entire sample (see King et al. 2001). This elutriation technique 
precluded analysis of the soil. Conversely, although the roots were removed from the soil samples in 2001, the roots were not analysed for $\delta^{13} \mathrm{C}$. The roots were not sampled in aspenmaple community in 1999.

Bulk density was measured in all years that soil analyses were conducted except 2001, 2003 and 2008. To calculate the C pool sizes in 2001 and 2003, we used the bulk density values for 2004. In 2008, we used bulk density values for 2007. We are confident in these substitutions as bulk density changed little through time (see results). Each bulk density measurement was corrected for the presence of coarse fragments.

From 2002 to 2008 , 4-12 litter traps $\left(0.15 \mathrm{~m}^{2}\right)$ were used to collect leaf litter from each of the three community types in each ring (Liu et al. 2005). Leaf litter was collected every two weeks during the period of active leaf senescence (late August through early November), and approximately monthly during the rest of the growing season. After collection, the leaf litter samples were sorted by species. These samples were then ground and used to create a biomass-weighted composite annual sample for analysis.

Stable isotope analysis for the soil, roots and leaf litter was conducted using a Costech (Valencia, CA, USA) Elemental Combustion System 4010 connected to a Thermo (Waltham, MA, USA) Finnigan ConfloIII Interface and Delta $^{\text {plus }}$ Continuous Flow-Stable Isotope Ratio Mass Spectrometer located at the Michigan Technological University Forest Ecology Analytical Laboratory. Samples were measured against a $\mathrm{CO}_{2}$ reference gas calibrated with IAEA (International Atomic Energy Agency, Vienna, Austria) reference materials. The $\mathrm{SD}$ of the measurements of a laboratory standard was $0.1 \%$ for $\delta^{13} \mathrm{C}$.

\section{Calculation of new soil $\mathrm{C}$}

To examine the input of recently fixed $\mathrm{C}$ into the soil under elevated $\mathrm{CO}_{2}$, we used methods similar to those in earlier reports on soil C formation and soil respiration at Rhinelander FACE (Loya et al. 2003; Pregitzer et al. 2006). Briefly, we used the depletion in $\delta^{13} \mathrm{C}$ caused by the use of fossil-fuel-derived $\mathrm{CO}_{2}$ for fumigation as a tracer in the treatment combinations receiving elevated $\mathrm{CO}_{2}\left(+\mathrm{CO}_{2}\right.$ and $\left.+\mathrm{CO}_{2}+\mathrm{O}_{3}\right)$. The proportional contribution $(f)$ of soil $\mathrm{C}$ derived from $\mathrm{C}$ fixed during the fumigation was calculated with the following equation:

$f=\left(\delta_{t}-\delta_{o}\right) /\left(\delta_{i}-\delta_{o}\right)$,

where $\delta_{t}$ is the current $\delta^{13} \mathrm{C}$ value for soil $\mathrm{C}, \delta_{o}$ is the $\delta^{13} \mathrm{C}$ value for soil $\mathrm{C}$ at the start of the experiment and $\delta_{i}$ is the $\delta^{13} \mathrm{C}$ value for $\mathrm{C}$ inputs from roots and leaves. $\delta_{i}$ values were calculated by averaging root and leaf $\delta^{13} \mathrm{C}$ values from growing seasons prior to the calculation year. Like the earlier reports from Rhinelander FACE (Loya et al. 2003; Pregitzer et al. 2006), we assumed equivalent inputs from fine roots $\left(<1 \mathrm{~mm}\right.$ in diameter) and leaf litter to calculate $\delta_{i}$. Unlike those reports, we did not assume equal leaf litter inputs from both species in the mixed species communities. Over time, competition has shifted the proportional contribution of each species to the total aboveground biomass (Kubiske et al. 2007). Instead, we adjusted the overall $\delta^{13} \mathrm{C}$ value of the leaf litter for each community according to the proportion of each species found in the leaf litter traps for that community in that year. Root biomass within a community is not differentiated by species. Roots and leaf litter were not sampled during every growing season. The only sampling of roots prior to 2003 occurred in 1999; the small size of the trees made leaf litter traps impractical prior to 2002. In years in which only one pool was sampled, we estimated the value of the missing input (leaves in 1999, roots in 2002) based on the average difference in $\delta^{13} \mathrm{C}$ between roots and leaves in each individual ring across all years. For the 2001 calculation of new soil $\mathrm{C}$, we assumed that $1999 \delta^{13} \mathrm{C}$ values (2002 values for the aspen-maple community) were representative of litter inputs prior to 2001. The mass of new $\mathrm{C}$ formed was computed by multiplying the fraction of new $\mathrm{C}$ by the size of the $\mathrm{C}$ pool. In addition, we calculated the mass of old soil $\mathrm{C}$ by subtracting the pool of new $\mathrm{C}$ from the total pool of $\mathrm{C}$.

\section{Statistical analysis}

The statistical model was a randomized complete block with a split-plot design; the analyses were conducted using the SAS statistical package (version 9.1.3; SAS Institute, Cary, NC, USA). The block was a fixed effect because of a known gradient in aspen productivity across the site. These analyses used type III sums of squares within PROC GLM (general linear model) with post-hoc LSMEANS (least squared means) Tukey's adjusted for multiple comparisons. Statistical analyses of fumigation effects closely followed those detailed in King et al. (2001) for this experiment, including specification of correct error terms for $F$-tests using test statements within SAS. In addition, we tested trends through time with logarithmic, exponential and linear regression models; the best fit among these models is reported. We used $\alpha=0.05$ to determine statistical significance. Given the difficulty of observing changes to soil bulk C pools (Hungate et al. 1996a), results of $0.05 \leq P<0.1$ were considered to be of marginal significance (Jastrow et al. 2005).

\section{RESULTS}

Prior to the initiation of our experiment, bulk density was greater under elevated $\mathrm{CO}_{2}$ and elevated $\mathrm{O}_{3}$ (Table 1). Post-hoc tests found that the $+\mathrm{CO}_{2}+\mathrm{O}_{3}$ treatment had a greater bulk density than the ambient $(P=0.033)$ and $+\mathrm{O}_{3}$ treatments $(P=0.093)$. In subsequent years, there were no significant fumigation effects on bulk density. Bulk density 
Table 1 Pre-treatment (1997) of soil carbon (C) traits (means \pm SE) and ANOva $P$-values. Carbon dioxide $\left(\mathrm{CO}_{2}\right)$ is not a factor in the analyses of $\delta^{13} \mathrm{C}$ because only elevated $\mathrm{CO}_{2}$ plots $\left(+\mathrm{CO}_{2}\right.$, $\left.+\mathrm{CO}_{2}+\mathrm{O}_{3}\right)$ were later fumigated with $\delta^{13} \mathrm{C}$-depleted $\mathrm{CO}_{2}$. Community is not a factor in this analysis because this sampling pre-dated the establishment of the model communities and did not distinguish between soils in the various parts of the rings. Effects with $P<0.1$ are in bold whereas those with $P<0.05$ are in bold and italics

\begin{tabular}{|c|c|c|c|c|}
\hline & $\begin{array}{l}\text { Bulk density } \\
\left(\mathrm{g} \mathrm{cm}^{-3}\right)\end{array}$ & $\begin{array}{l}\text { Carbon } \\
\left(\mathrm{mg} \mathrm{g}^{-1}\right)\end{array}$ & $\begin{array}{l}\text { Carbon } \\
\left(\mathrm{Mg} \mathrm{ha}^{-1}\right)\end{array}$ & $\begin{array}{l}\text { Soil } \delta^{13} \mathrm{C} \\
(\%)\end{array}$ \\
\hline \multicolumn{5}{|l|}{ Treatment } \\
\hline Ambient & $1.2 \pm 0.0$ & $15.4 \pm 1.5$ & $37.2 \pm 4.1$ & - \\
\hline$+\mathrm{CO}_{2}$ & $1.3 \pm 0.1$ & $15.2 \pm 0.5$ & $39.5 \pm 0.9$ & $-26.4 \pm 0.0$ \\
\hline$+\mathrm{O}_{3}$ & $1.3 \pm 0.0$ & $15.0 \pm 1.5$ & $37.8 \pm 4.0$ & - \\
\hline$+\mathrm{CO}_{2}+\mathrm{O}_{3}$ & $1.4 \pm 0.0$ & $13.0 \pm 1.1$ & $37.2 \pm 3.6$ & $-26.1 \pm 0.2$ \\
\hline \multicolumn{5}{|l|}{ Source } \\
\hline $\mathrm{CO}_{2}$ & 0.018 & 0.453 & 0.831 & - \\
\hline $\mathrm{O}_{3}$ & 0.071 & 0.381 & 0.835 & 0.251 \\
\hline $\mathrm{CO}_{2} \times \mathrm{O}_{3}$ & 0.394 & 0.550 & 0.736 & - \\
\hline
\end{tabular}

Table 2 ANOva $P$-values for the differences in overall soil carbon $(\mathrm{C})$ traits, isotopically new $\mathrm{C}$ and old soil $\mathrm{C}$. Carbon dioxide $\left(\mathrm{CO}_{2}\right)$ is not a factor in the analyses of new and old $\mathrm{C}$ because only elevated $\mathrm{CO}_{2}$ plots $\left(+\mathrm{CO}_{2}\right.$, $\left.+\mathrm{CO}_{2}+\mathrm{O}_{3}\right)$ were fumigated with $\delta^{13} \mathrm{C}-$ depleted $\mathrm{CO}$. Effects with $P<0.1$ are in bold whereas those with $P<0.05$ are in bold and italics

\begin{tabular}{|c|c|c|c|c|c|c|}
\hline Source & $\begin{array}{l}\text { Carbon } \\
\left(\mathrm{mg} \mathrm{g}^{-1}\right)\end{array}$ & $\begin{array}{l}\text { Bulk density } \\
\left(\mathrm{g} \mathrm{cm}^{-3}\right)\end{array}$ & $\begin{array}{l}\text { Carbon } \\
\left(\mathrm{Mg} \mathrm{ha}^{-1}\right)\end{array}$ & $\begin{array}{l}\text { New } \\
\text { carbon (\%) }\end{array}$ & $\begin{array}{l}\text { New carbon } \\
\left(\mathrm{Mg} \mathrm{ha}^{-1}\right)\end{array}$ & $\begin{array}{l}\text { Old carbon } \\
\left(\mathrm{Mg} \mathrm{ha}^{-1}\right)\end{array}$ \\
\hline $\mathrm{CO}_{2}$ & 0.406 & 0.894 & 0.365 & - & - & - \\
\hline $\mathrm{O}_{3}$ & 0.365 & 0.502 & 0.413 & 0.548 & 0.148 & 0.645 \\
\hline $\mathrm{CO}_{2} \times \mathrm{O}_{3}$ & 0.660 & 0.710 & 0.452 & - & - & - \\
\hline Community & 0.896 & 0.457 & 0.956 & 0.024 & 0.262 & 0.027 \\
\hline $\mathrm{CO}_{2} \times$ community & 0.174 & 0.083 & 0.095 & - & - & - \\
\hline $\mathrm{O}_{3} \times$ community & 0.293 & 0.995 & 0.390 & 0.967 & 0.812 & 0.201 \\
\hline $\mathrm{CO}_{2} \times \mathrm{O}_{3} \times$ community & 0.823 & 0.577 & 0.704 & - & - & - \\
\hline Time & $<0.001$ & 0.001 & $<0.001$ & $<0.001$ & $<0.001$ & 0.247 \\
\hline $\mathrm{CO}_{2} \times$ time & 0.348 & 0.616 & 0.343 & - & - & - \\
\hline $\mathrm{O}_{3} \times$ time & 0.965 & 0.283 & 0.990 & 0.821 & 0.686 & 0.979 \\
\hline $\mathrm{CO}_{2} \times \mathrm{O}_{3} \times$ time & 0.993 & 0.268 & 0.983 & - & - & - \\
\hline Community $\times$ time & 0.628 & 0.565 & 0.784 & 0.101 & 0.441 & 0.025 \\
\hline $\mathrm{CO}_{2} \times$ community $\times$ time & 0.106 & 0.383 & 0.061 & - & - & - \\
\hline $\mathrm{O}_{3} \times$ community $\times$ time & 0.487 & 0.559 & 0.507 & 0.923 & 0.941 & 0.582 \\
\hline $\mathrm{CO}_{2} \times \mathrm{O}_{3} \times$ community $\times$ time & 0.846 & 0.275 & 0.936 & - & - & - \\
\hline
\end{tabular}

differed between individual years (Tables 2 and S1), but there were no significant trends over time in bulk density between 2004 and $2007\left(R^{2}<0.1, P>0.5\right)$. Before the start of fumigation, there were no significant differences in soil $\mathrm{C}$ concentrations (Table 1). Subsequently, overall concentrations increased linearly from $13.4 \mathrm{mg} \mathrm{g}^{-1}$ (SE: \pm 0.8$)$ in 2001 to $16.0 \mathrm{mg} \mathrm{g}^{-1}( \pm 0.6)$ in $2008\left(R^{2}=0.751, P=0.012\right)$. Likewise, soil $\mathrm{C}$ content did not significantly differ among treatments prior to fumigation (Table 1), and overall increased linearly from $33.5 \mathrm{Mg} \mathrm{ha}^{-1}( \pm 2.3)$ in 2001 to $40.1 \mathrm{Mg} \mathrm{ha}{ }^{-1}( \pm 1.6)$ in $2008\left(R^{2}=0.707, \quad P=0.017\right.$; Table S1).

After 11 years of fumigation, the effects on soil $\mathrm{C}$ content were negative for $+\mathrm{CO}_{2}\left(-2.2 \mathrm{Mg} \mathrm{ha}{ }^{-1}\right)$ and $+\mathrm{CO}_{2}+\mathrm{O}_{3}$ $\left(-6.1 \mathrm{Mg} \mathrm{ha}^{-1}\right)$ relative to ambient, but positive for $+\mathrm{O}_{3}$ $\left(+1.4 \mathrm{Mg} \mathrm{ha}^{-1}\right)$; these effects varied by community. For instance, the overall $\mathrm{CO}_{2}$ effect $\left(+\mathrm{CO}_{2}\right.$ and $+\mathrm{CO}_{2}+\mathrm{O}_{3}$ pooled vs. ambient and $+\mathrm{O}_{3}$ pooled) on soil $\mathrm{C}$ content in 2008 was large and negative in the aspen-only community $\left(-17.4 \mathrm{Mg} \mathrm{ha}^{-1}\right)$, but small and positive in the aspenmaple (+1.7 $\left.\mathrm{Mg} \mathrm{ha}^{-1}\right)$ and aspen-birch (+1.0 $\left.\mathrm{Mg} \mathrm{ha}^{-1}\right)$ communities. Similarly, the overall $\mathrm{O}_{3}$ effect was negative in the aspen-only $\left(-2.3 \mathrm{Mg} \mathrm{ha}^{-1}\right)$ and the aspenmaple $\left(-4.0 \mathrm{Mg} \mathrm{ha}^{-1}\right)$ communities, but positive in the aspen-birch community $\left(+2.6 \mathrm{Mg} \mathrm{ha}^{-1}\right)$. Consequently, there were no significant main effects of the fumigation treatments on soil $\mathrm{C}$ content $(P>0.35$; Table 2$)$. However, there were marginally significant interactive effects on soil $\mathrm{C}$ 


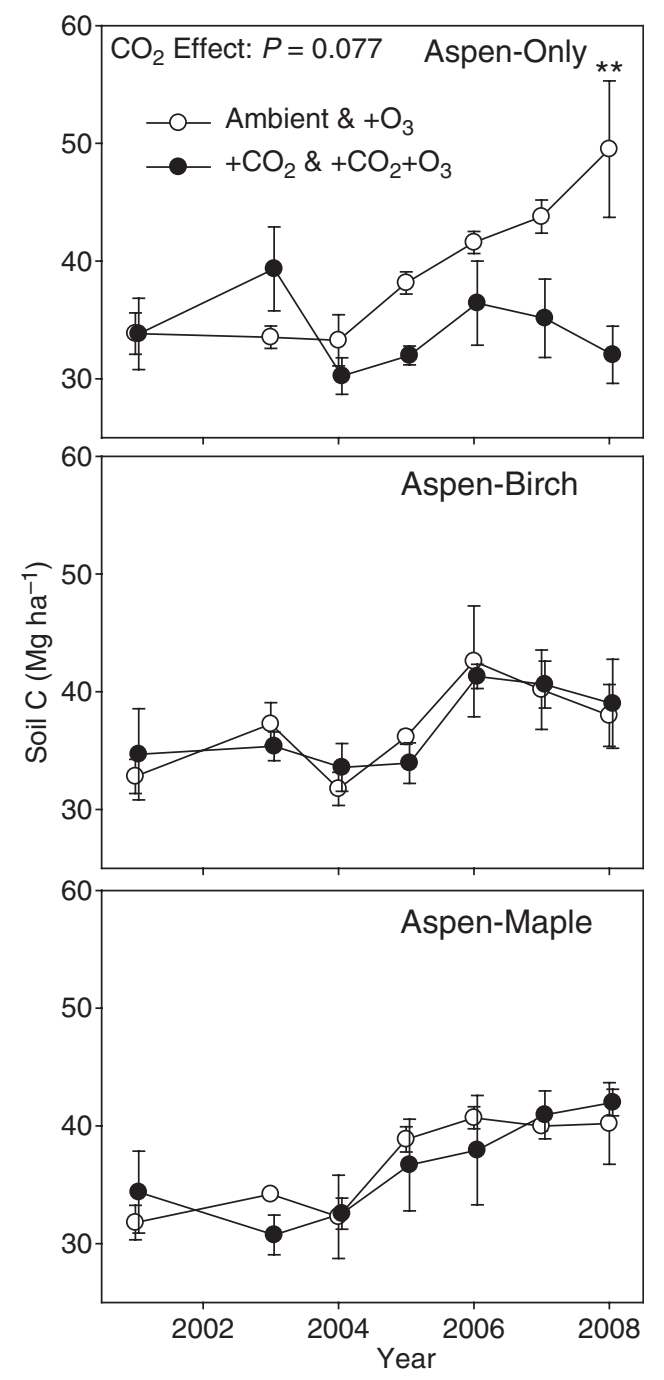

Figure 1 Mean surface mineral soil carbon $(C ; 0-20 \mathrm{~cm})$ for the three community types under ambient carbon dioxide $\left(\mathrm{CO}_{2}\right.$; ambient and $\left.+\mathrm{O}_{3}\right)$ and elevated $\mathrm{CO}_{2}\left(+\mathrm{CO}_{2}\right.$ and $\left.+\mathrm{CO}_{2}+\mathrm{O}_{3}\right)$. Error bars are \pm 1 SE. Reported $P$-values are from post-hoc Tukey's tests. Asterisks denote the significant $\mathrm{CO}_{2}$ effect in 2008 in the aspen-only community $(P=0.003)$.

content (community $\times \mathrm{CO}_{2}$, community $\times \mathrm{CO}_{2} \times$ time, $P<0.1$; Table 2). Post-hoc tests revealed that the effect of $\mathrm{CO}_{2}$ on soil $\mathrm{C}$ content was most significant in the aspen-only community $(P=0.077)$, particularly in 2008 ( $P=0.003$; Fig. 1$)$. When the aspen-only community data were analysed separately to explore the effects in this community, both $\mathrm{CO}_{2}$ and $\mathrm{CO}_{2} \times$ time significantly affected soil $\mathrm{C}$ content ( $P=0.042$ and 0.046 , respectively). This $\mathrm{CO}_{2}$ effect was not a loss of soil $\mathrm{C}$ per se, but a lack of accrual over the last several measurements. The significant interaction between $\mathrm{CO}_{2}$ and time occurred because there was a linear increase in soil $\mathrm{C}$ content from

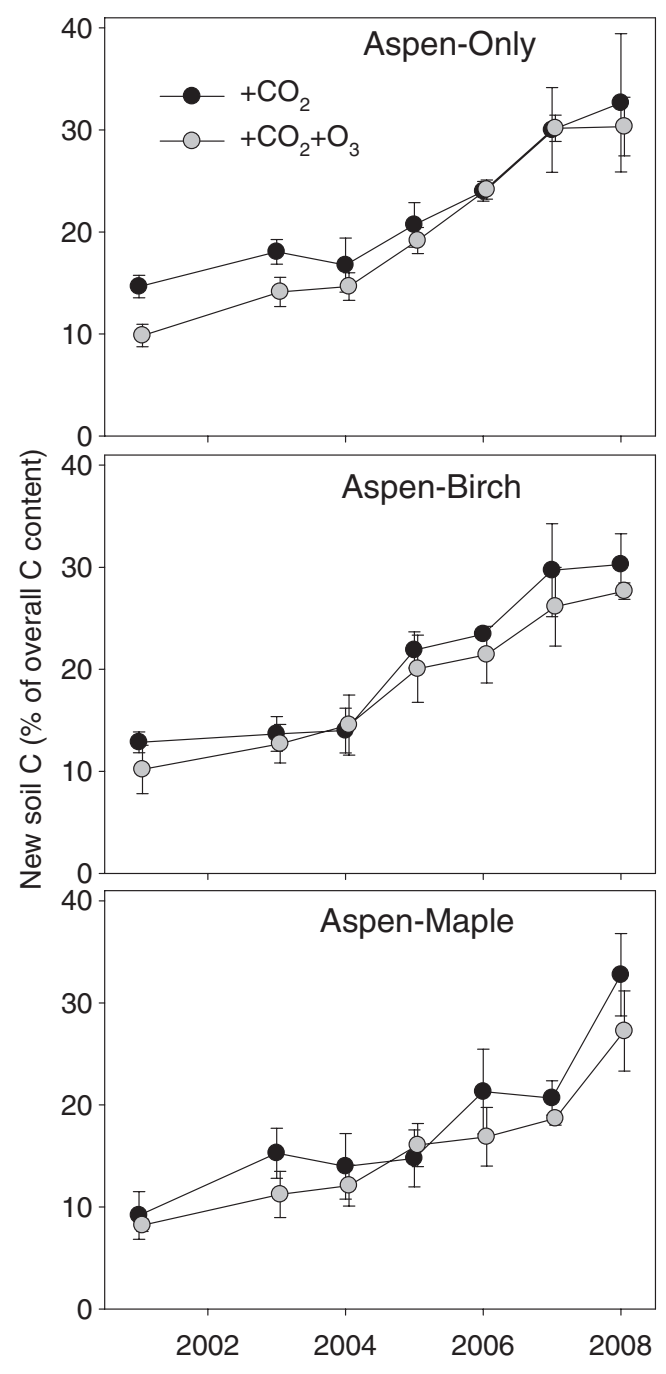

Figure 2 The annual proportion of new surface mineral soil carbon (C; fixed since 1998; 0-20 cm) for the three community types in the plots fumigated with elevated carbon dioxide $\left(\mathrm{CO}_{2}\right)$ and either ambient $\left(+\mathrm{CO}_{2}\right)$ or elevated $\mathrm{O}_{3}\left(+\mathrm{CO}_{2}+\mathrm{O}_{3}\right)$. Error bars are $\pm 1 \mathrm{SE}$. Ozone effects were not statistically significant.

2001 to 2008 in the aspen-only community under ambient $\mathrm{CO}_{2}\left(R^{2}=0.784, \quad P=0.005\right)$, but no clear trend of accumulation over time under elevated $\mathrm{CO}_{2}\left(R^{2}=0.026\right.$, $P=0.732$; Fig. 1).

Surface mineral soil $\delta^{13} \mathrm{C}$ values prior to fumigation were not significantly different between the $+\mathrm{CO}_{2}$ and $+\mathrm{CO}_{2}+\mathrm{O}_{3}$ treatments (Table 1). The per cent of new $\mathrm{C}$ (Fig. 2) and the pool of new $\mathrm{C}$ formed in the treatments fumigated with elevated $\mathrm{CO}_{2}\left(+\mathrm{CO}_{2},+\mathrm{CO}_{2}+\mathrm{O}_{3}\right)$ grew exponentially between 2001 and $2008\left(R^{2}>0.97, P<0.001\right.$ overall). Over the course of the experiment, the average annual increases in the new $\mathrm{C}$ content for the $+\mathrm{CO}_{2}$ and $+\mathrm{CO}_{2}+\mathrm{O}_{3}$ treatments were $1.45 \mathrm{Mg} \mathrm{ha}{ }^{-1}$ per year $( \pm 0.23)$ 
and $1.27 \mathrm{Mg} \mathrm{ha}^{-1}$ per year $( \pm 0.09)$, respectively. These values are approximately $3 \%$ of the overall $\mathrm{C}$ pool.

The proportion of new $\mathrm{C}$ added to the soil over the course of the study differed by community (Table 2 and Fig. 3), wherein the per cent of new $\mathrm{C}$ in the soil was significantly lower in the aspen-maple community than in the aspen-only community $(P=0.021)$. New soil $\mathrm{C}$ content $\left(\mathrm{Mg} \mathrm{ha}{ }^{-1}\right)$ did not differ among communities or treatments (Tables 2 and S2). However, old soil C content did differ among communities (Table 2 and Fig. 3); the aspen-only community had less old $\mathrm{C}$ over the course of the study than either the aspen-maple $(P=0.028)$ or aspen-birch community $(P=0.074)$. These community differences were not initially present (2001), but developed over time (community $\times$ time: $P=0.025)$. The aspen-only community lost old $C$ at a rate of $0.83 \mathrm{Mg} \mathrm{ha}^{-1}$ per year $( \pm 0.24)$ between 2001 and 2008 (linear: $R^{2}=0.57, P=0.050$ ), whereas the aspenbirch and aspen-maple communities lost $0.46 \mathrm{Mg} \mathrm{ha}^{-1}$ per year $( \pm 0.20)$ and $0.43 \mathrm{Mg} \mathrm{ha}^{-1}$ per year $( \pm 0.33)$ of old $\mathrm{C}$ and did not show significant trends in the loss of old $\mathrm{C}$ through time $(P>0.4)$
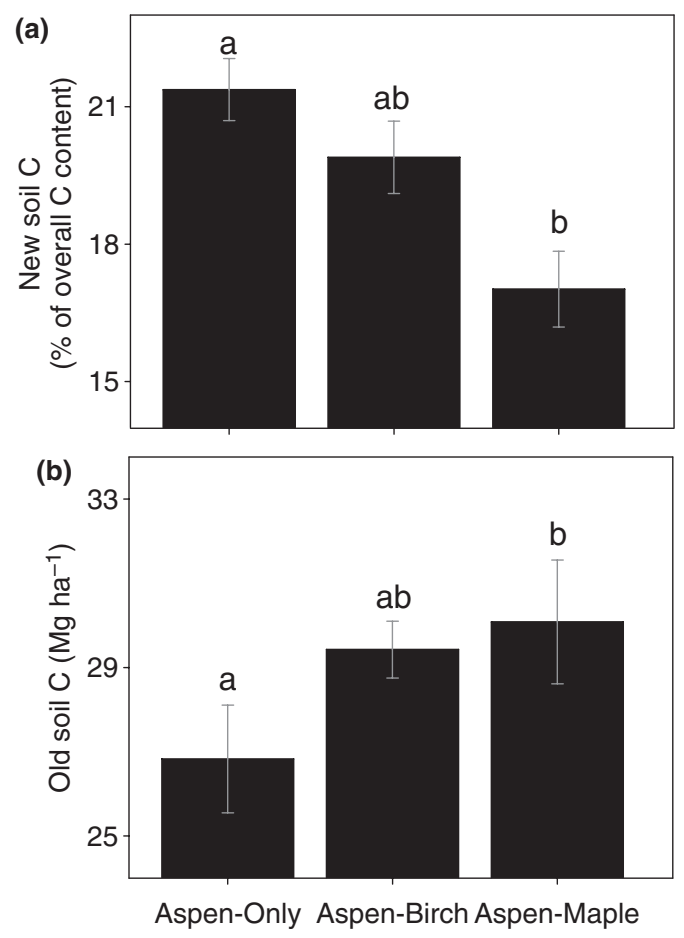

Figure 3 The (a) proportion of new surface mineral soil carbon (C; fixed since 1998; 0-20 cm) and (b) the pool of old soil C in the plots fumigated with elevated carbon dioxide $\left(+\mathrm{CO}_{2}\right.$ and $+\mathrm{CO}_{2}+\mathrm{O}_{3}$ ) for each of the three community types averaged through time (2001-2008) and across treatments $\left(+\mathrm{CO}_{2}\right.$ and $\left.+\mathrm{CO}_{2}+\mathrm{O}_{3}\right)$. Different letters denote significant differences among the communities $(P<0.05)$.
When first measured (2001), fumigation with $\mathrm{O}_{3}$ reduced the proportion of new $\mathrm{C}$ by almost a quarter $\left(+\mathrm{CO}_{2}\right.$, $\left.12.2 \pm 0.6 \% ;+\mathrm{CO}_{2}+\mathrm{O}_{3}, 9.4 \pm 1.3 \%\right)$ and new $\mathrm{C}$ content by almost a third $\left(+\mathrm{CO}_{2}, 4.5 \pm 0.8 \mathrm{Mg} \mathrm{ha}{ }^{-1} ;+\mathrm{CO}_{2}+\mathrm{O}_{3}\right.$, $\left.3.1 \pm 0.5 \mathrm{Mg} \mathrm{ha}^{-1}\right)$, although these differences were not significant $(P=0.798$ and 0.704 , respectively; Fig. 2 and Table S2). In subsequent years, the amount of new soil $\mathrm{C}$ in the $+\mathrm{CO}_{2}$ and $+\mathrm{CO}_{2}+\mathrm{O}_{3}$ treatments converged. Averaged over the last four years of the study, $+\mathrm{CO}_{2}+\mathrm{O}_{3}$ reduced the proportion of new $\mathrm{C}$ by only $8 \%\left(+\mathrm{CO}_{2}, 25.2 \pm 2.4 \%\right.$; $+\mathrm{CO}_{2}+\mathrm{O}_{3}, 22.2 \pm 1.4 \%$ ) and new $\mathrm{C}$ content over this period by only $14 \%\left(+\mathrm{CO}_{2}, 9.7 \pm 0.5 \mathrm{Mg} \mathrm{ha}{ }^{-1} ;+\mathrm{CO}_{2}+\mathrm{O}_{3}\right.$, $\left.8.3 \pm 0.6 \mathrm{Mg} \mathrm{ha}^{-1}\right)$. Overall, there was no significant effect of $\mathrm{O}_{3}$ on the percentage of new $\mathrm{C}$ formed under elevated $\mathrm{CO}_{2}$. Furthermore, there were no significant interactions among $\mathrm{O}_{3}$, community and time (Table 2). The amount of old soil $\mathrm{C}$ present was also not significantly affected by $\mathrm{O}_{3}$ or the interactions of $\mathrm{O}_{3}$ with community and/or time (Table 2).

\section{DISCUSSION}

\section{Elevated $\mathrm{CO}_{2}$ effects on soil $\mathrm{C}$ content}

Meta-analyses of elevated $\mathrm{CO}_{2}$ experiments (Jastrow et al. 2005; Luo et al. 2006) and results from other forest FACE studies have shown that elevated $\mathrm{CO}_{2}$ tends to increase the rate of soil C storage (Jastrow et al. 2005; Hoosbeek et al. 2006), although not always significantly (Lichter et al. 2005). We predicted that elevated $\mathrm{CO}_{2}\left(+\mathrm{CO}_{2}\right.$, $\left.+\mathrm{CO}_{2}+\mathrm{O}_{3}\right)$ would raise surface mineral soil $\mathrm{C}$ content, but there was not a significant increase in soil $\mathrm{C}$ content in any of the three forest communities and the overall $\mathrm{CO}_{2}$ effect on soil $\mathrm{C}$ content was slightly negative. Our results are interesting in the context of our overall experiment, where elevated $\mathrm{CO}_{2}$ has caused clear increases in litter inputs to the soil. For instance, although $\mathrm{CO}_{2}$ had a large negative effect on soil $\mathrm{C}$ content in the aspen-only community (Fig. 1), this community exhibited a $\mathrm{CO}_{2}$ stimulation of $25 \%$ for leaf litter mass (Pregitzer \& Talhelm, unpublished data) and 40\% for fine root mass in 2005 (Pregitzer et al. 2008). This implies that the decomposition of organic matter has accelerated under elevated $\mathrm{CO}_{2}$. This response is consistent with the greater rates of soil nitrogen cycling that we have previously observed (Holmes et al. 2006), as well as with the higher activity of extracellular enzymes mediating cellulose and chitin degradation (Larson et al. 2002).

It has been proposed that elevated $\mathrm{CO}_{2}$ will change litter chemistry and alter decomposition (Norby et al. 2001). Decomposition studies at Rhinelander FACE found that litter decay rates over 2 years decreased (Parsons et al. 2008) or did not change (Chapman et al. 2005) under elevated $\mathrm{CO}_{2}$, but extrapolations to determine longer-term effects 
were inconclusive (Parsons et al. 2008). Similarly, a metaanalysis found no significant effect of elevated $\mathrm{CO}_{2}$ on decomposition, but cautioned that long-term effects needed further examination (Norby et al. 2001). Together, these results suggest that changes in the initial stages of litter decomposition are not a likely cause of the lack of soil C accumulation in our study.

Several studies have revealed that increases in C inputs to the soil, particularly greater root growth, can enhance the decomposition of existing soil organic matter (Fontaine et al. 2004; Hoosbeek et al. 2004; Trueman \& Gonzalez-Meler 2005; Carney et al. 2007; Dijkstra \& Cheng 2007). The results of these studies may be due to a 'priming' effect, the stimulation of microbial activity and decomposition in response to new inputs of organic matter (Fontaine et al. 2004). Recent modelling results suggest that a greater loss of old soil $\mathrm{C}$ under elevated $\mathrm{CO}_{2}$ may negate gains in new $\mathrm{C}$ (Niklaus \& Falloon 2006). Consistent with this idea, two forest experiments have observed lower total soil $\mathrm{C}$ under elevated $\mathrm{CO}_{2}$ that resulted from greater losses of older soil C (Hoosbeek et al. 2004; Langley et al. 2009). Although the largest loss of old soil $\mathrm{C}$ under elevated $\mathrm{CO}_{2}\left(+\mathrm{CO}_{2}\right.$ and $\left.+\mathrm{CO}_{2}+\mathrm{O}_{3}\right)$ in our experiment occurred in the aspen-only community (Fig. 3), we cannot conclude that the loss of old $\mathrm{C}$ caused the significant $\mathrm{CO}_{2}$ effect because we do not know the fate of old $\mathrm{C}$ under ambient $\mathrm{CO}_{2}$.

\section{Effects of $\mathrm{O}_{3}$ on soil C formation}

The initial (2001) assessment of soil C formation under elevated $\mathrm{CO}_{2}$ revealed that elevated $\mathrm{O}_{3}$ reduced new $\mathrm{C}$ content in the aspen-only and aspen-birch communities (Loya et al. 2003). It is now clear that this was a transient effect (Fig. 2). The most recent estimates of NPP found that the phyto-toxic effects of $\mathrm{O}_{3}$ on NPP were apparent under both ambient and elevated $\mathrm{CO}_{2}$ (King et al. 2005), so it was surprising that concurrent fumigation with $\mathrm{O}_{3}$ has not reduced the proportion of recently fixed $\mathrm{C}$ in the soil under elevated $\mathrm{CO}_{2}$ or had a meaningful effect on the overall surface mineral soil C pool.

The early results of reduced soil $\mathrm{C}$ formation matched observations on allocation to fine roots $(<1 \mathrm{~mm}$ in diameter), which were initially suppressed by fumigation with $\mathrm{O}_{3}$ (King et al. 2001). However, since that time, the effect of $\mathrm{O}_{3}$ on fine root biomass has reversed, wherein fine root biomass is now greatest in the $+\mathrm{CO}_{2}+\mathrm{O}_{3}$ treatment (Pregitzer et al. 2008). This fine root response is likely why the earlier gap in new soil $\mathrm{C}$ between the $+\mathrm{CO}_{2}+\mathrm{O}_{3}$ and $+\mathrm{CO}_{2}$ treatments narrowed in the later years. Over the course of the experiment, dominance by more $\mathrm{O}_{3}$-tolerant plant genotypes and species has increased under elevated $\mathrm{O}_{3}$ (Zak et al. 2007). This change towards a less $\mathrm{O}_{3}$-responsive plant community and an increase in the proportional allocation of $\mathrm{C}$ to roots under elevated $\mathrm{O}_{3}$ (Pregitzer et al. 2008) are responsible likely for the increased root biomass under elevated $\mathrm{O}_{3}$.

\section{Soil C turnover}

Our mixing model for determining new soil $\mathrm{C}$ assumed a 50/50 mix of roots and leaves as inputs, an assumption which may not be accurate (Hobbie et al. 2004). However, the average difference between leaves and roots in $\delta^{13} \mathrm{C}$ was small $(<0.5 \%)$. Consequently, altering the mixing model to $75 \%$ roots $/ 25 \%$ leaves or $25 \%$ roots $/ 75 \%$ leaves only changed the proportion of new $\mathrm{C}$ in 2008 from $30.2 \%$ to $30.3 \%$ or $30.0 \%$. Furthermore, these changes in the mixing model had no meaningful statistical consequences (Table S3).

The trends in accrual of new C from 2001 and 2008 suggest that the pool of new $\mathrm{C}$ has not yet reached equilibrium (Fig. 2). Most models of soil C cycling include pools of $\mathrm{C}$ with both long and short turnover times, with pools that turnover quickly containing large portions of the total soil C (Trumbore 2000; Jenkinson \& Coleman 2008). This explains the apparent contrast between our study, in which roughly one-third of the soil $\mathrm{C}$ pool is new $\mathrm{C}$ after 11 years, and the many studies using ${ }^{14} \mathrm{C}$ that estimate the average age of soil $\mathrm{C}$ to range from 200 to 1300 years (Trumbore 2000). The results from Rhinelander FACE also contrast with a pasture FACE study where the amount of new $\mathrm{C}$ began to plateau at $\sim 25 \%$ of the soil $\mathrm{C}$ pool during the middle of the 10 years of $\mathrm{CO}_{2}$ fumigation (van Kessel et al. 2006). The pasture FACE study examined the surface $10 \mathrm{~cm}$ of soil, whereas our study encompassed a greater depth $(20 \mathrm{~cm})$; earlier work from the pasture FACE experiment found new soil $\mathrm{C}$ accruing more slowly at 10-25 cm (van Kessel et al. 2000) and the differences in sampling depth may explain why the accrual of new $\mathrm{C}$ at Rhinelander FACE has been relatively slower to plateau.

The Rhinelander FACE study is similar to other elevated $\mathrm{CO}_{2}$ studies in the size of the recent $\mathrm{C}$ flux into the soil $\mathrm{C}$ pool. Most elevated $\mathrm{CO}_{2}$ studies fumigated with ${ }^{13} \mathrm{C}$ depleted $\mathrm{CO}_{2}$ have found that annual inputs of new $\mathrm{C}$ are 2-5\% of the overall soil C pool (Leavitt et al. 1994, 2001; Hagedorn et al. 2001; Lichter et al. 2005; Xie et al. 2005; van Kessel et al. 2006). Comparatively, the mass-based flux of new $\mathrm{C}$ into the total soil pool appears to be more variable, ranging from less than $0.5 \mathrm{Mg} \mathrm{ha}^{-1}$ per year (Leavitt et al. 2001) to more than $6 \mathrm{Mg} \mathrm{ha}^{-1}$ per year (van Kessel et al. 2000). However, a number of studies have documented rates that are similar to our study, c. $1.0-1.5 \mathrm{Mg} \mathrm{C} \mathrm{ha}^{-1}$ per year (Hagedorn et al. 2001; Lichter et al. 2005; Xie et al. 2005; van Kessel et al. 2006). This is similar to the range of average annual inputs to the soil in several ecosystems based 
on bomb ${ }^{14} \mathrm{C}$ methodology $\left(0.8-1.4 \mathrm{Mg} \mathrm{C}\right.$ ha ${ }^{-1}$ per year; Trumbore 2000).

\section{Plant community effects}

In this study, soil $\mathrm{C}$ cycling has differed among communities, with a lower proportion of new soil $\mathrm{C}$ in the aspenmaple community (Fig. 3), and a steady decrease in old soil $\mathrm{C}$ over time and a negative $\mathrm{CO}_{2}$ effect on total $\mathrm{C}$ found solely in the aspen-only community (Fig. 1). The presence of community differences might be expected because species-specific effects on soil properties are commonly observed (Binkley \& Giardina 1998) and because specieslevel controls on the cycling of soil organic matter under elevated $\mathrm{CO}_{2}$ have been noted in the past (Hungate et al. 1996b; Dijkstra et al. 2004). Some species effects on soil properties are driven by differences in litter production (Binkley \& Giardina 1998). The amounts of new and old C in the aspen-only and aspen-maple communities (Fig. 3) are congruent with this idea because these communities have the highest and lowest NPP (King et al. 2005) and fine root biomass (Pregitzer et al. 2008) under elevated $\mathrm{CO}_{2}$. At least under elevated $\mathrm{CO}_{2}$, NPP appears to be a key factor in creating the community-level differences in soil $\mathrm{C}$ cycling. However, the aspen-only and aspen-birch communities differ by only a few per cent in both NPP and leaf litter production under elevated $\mathrm{CO}_{2}$ (King et al. 2005; Pregitzer \& Talhelm, unpublished data), but these communities have shown very different responses to $\mathrm{CO}_{2}$ in terms of soil $\mathrm{C}$ content (Fig. 1). These results suggest that factors other than NPP have created the observed differences in soil C content under elevated $\mathrm{CO}_{2}$.

Tissue chemistry responses to elevated $\mathrm{CO}_{2}$ that vary among communities may also be responsible for the observed differences in community responses. For instance, elevated $\mathrm{CO}_{2}$ has increased the concentration of condensed tannins in the aspen-birch community but decreased the concentration of condensed tannins in the aspen-only community (Liu et al. 2005). Condensed tannins are relatively recalcitrant compounds, which can slow down the microbial transformations of nitrogen (Maie et al. 2003) and tannin concentrations could be influencing decomposition. However, it is beyond the scope of our study to determine whether such a change influences soil C pools. Rather, our point is that species and genotypes respond to global change agents such as elevated $\mathrm{CO}_{2}$ in individualistic ways (Bradley \& Pregitzer 2007). The results from our study demonstrate how these species-specific responses make it challenging to predict the extent to which elevated $\mathrm{CO}_{2}$ and $\mathrm{O}_{3}$ will influence the biogeochemical cycling of $\mathrm{C}$. Other than time, the interaction between community type and $\mathrm{CO}_{2}$ was the most significant factor driving change in soil $\mathrm{C}$ at Rhinelander FACE (Fig. 1).

\section{Implications}

The Rhinelander FACE experiment has generated several unexpected results: lower soil $\mathrm{C}$ under elevated $\mathrm{CO}_{2}$ in the aspen-only community and the transient effect of $+\mathrm{CO}_{2}+\mathrm{O}_{3}$ on soil $\mathrm{C}$ formation, soil respiration and fine root biomass (Pregitzer et al. 2008). That each of these unexpected responses developed only after years of fumigation demonstrates the necessity of long-term experiments for the understanding of global change ecology. Across the study, community differences controlled the accrual of total $\mathrm{C}$, inputs of new $\mathrm{C}$ and the loss of old $\mathrm{C}$ over time. These community-specific responses mean that care must be taken in selecting species for forestry-based $\mathrm{C}$ sequestration programmes. Overall, our results do not match most conceptualizations of how soil organic matter dynamics will be altered by changing concentrations of $\mathrm{CO}_{2}$ (McMurtrie et al. 2000; Luo et al. 2006) and $\mathrm{O}_{3}$ (Ren et al. 2007; Sitch et al. 2007). Particularly for $\mathrm{O}_{3}$, the effects on soil $\mathrm{C}$ appear to have been overstated. The composition of the dominant plant community, competitive interactions and positive feedbacks on microbial communities appear to play the most important role in controlling the pool of surface mineral soil C through time.

\section{ACKNOWLEDGEMENTS}

The authors thank Angela Piket, Jennifer Eikenberry and numerous other technicians who have helped in the field and lab during this experiment. Dale W. Johnson provided valuable comments on earlier drafts of the manuscript. Rhinelander FACE is principally supported by the U.S. Department of Energy's Office of Biological and Environmental Research and the U.S. Forest Service. This is a publication of the Nevada Agricultural Experiment Station.

\section{REFERENCES}

Ainsworth, E.A. \& Long, S.P. (2005). What have we learned from 15 years of free-air $\mathrm{CO}_{2}$ enrichment (FACE)? A meta-analytic review of the responses of photosynthesis, canopy properties and plant production to rising $\mathrm{CO}_{2}$. New Phytol., 165, 351-372.

Binkley, D. \& Giardina, C. (1998). Why do tree species affect soils? The Warp and Woof of tree-soil interactions. Biogeochemistry, 42, 89-106.

Bradley, K.L. \& Pregitzer, K.S. (2007). Ecosystem assembly and terrestrial carbon balance under elevated $\mathrm{CO}_{2}$. Trends Ecol. Evol., 22, 538-547.

Carney, K.M., Hungate, B.A., Drake, B.G. \& Megonigal, J.P. (2007). Altered soil microbial community at elevated $\mathrm{CO}_{2}$ leads to loss of soil carbon. Proc. Natl. Acad. Sci., 104, 4990-4995.

Chapman, J.A., King, J.S., Pregitzer, K.S. \& Zak, D.R. (2005). Effects of elevated concentrations of atmospheric $\mathrm{CO}_{2}$ and tropospheric $\mathrm{O}_{3}$ on decomposition of fine roots. Tree Physiol., 25, 1501-1510. 
Dentener, F., Stevenson, D., Ellingsen, K., van Noije, T., Schultz, M., Amann, M. et al. (2006). The global atmospheric environment for the next generation. Environ. Sci. Technol., 40, 3586-3594.

Dijkstra, F.A. \& Cheng, W. (2007). Interactions between soil and tree roots accelerate long-term soil carbon decomposition. Ecol. Lett., 10, 1046-1053.

Dijkstra, F.A., Hobbie, S.E., Knops, J.M.H. \& Reich, P.B. (2004). Nitrogen deposition and plant species interact to influence soil carbon stabilization. Ecol. Lett., 7, 1192-1198.

Fontaine, S., Bardoux, G., Abbadie, L. \& Mariotti, A. (2004). Carbon input to soil may decrease soil carbon content. Ecol. Lett., 7, 314-320.

de Graaff, M.-A., van Groenigen, K.-J., Six, J., Hungate, B. \& van Kessel, C. (2006). Interactions between plant growth and soil nutrient cycling under elevated $\mathrm{CO}_{2}$ : a meta-analysis. Global Change Biol., 12, 2077-2091.

Grantz, D.A., Gunn, S. \& Vu, H.-B. (2006). $\mathrm{O}_{3}$ impacts on plant development: a meta-analysis of root/shoot allocation and growth. Plant Cell Environ., 29, 1193-1209.

Hagedorn, F., Maurer, S., Egli, P., Blaser, P., Bucher, J.B. \& Siegwolf, R. (2001). Carbon sequestration in forest soils: effects of soil type, atmospheric $\mathrm{CO}_{2}$ enrichment, and $\mathrm{N}$ deposition. Eur. J. Soil Sci., 52, 619-628.

Hobbie, E.A., Johnson, M.G., Rygiewicz, P.T., Tingey, D.T. \& Olszyk, D.M. (2004). Isotopic estimates of new carbon inputs into litter and soils in a four-year climate change experiment with Douglas-fir. Plant Soil, 259, 331-343.

Holmes, W.E., Zak, D.R., Pregitzer, K.S. \& King, J.S. (2006). Elevated $\mathrm{CO}_{2}$ and $\mathrm{O}_{3}$ alter soil nitrogen transformations beneath trembling aspen, paper birch, and sugar maple. Ecosystems, 9, 1354-1363.

Hoosbeek, M.R., Lukac, M., van Dam, D., Godbold, D.L., Velthorst, E.J., Biondi, F.A. et al. (2004). More new carbon in the mineral soil of a poplar plantation under Free Air Carbon Enrichment (POPFACE): cause of increased priming effect? Global Biogeochem. Cycles, 18, GB1040.

Hoosbeek, M.R., Li, Y. \& Scarascia-Mugnozza, G.E. (2006). Free atmospheric $\mathrm{CO}_{2}$ enrichment (FACE) increased labile and total carbon in the mineral soil of a short rotation poplar plantation. Plant Soil, 281, 247-254.

Hungate, B.A., Jackson, R.B., Field, C.B. \& Chapin, F.S. III (1996a). Detecting changes in soil carbon in $\mathrm{CO}_{2}$ enrichment experiments. Plant Soil, 187, 135-145.

Hungate, B.A., Canadell, J. \& Chapin, F.S. (1996b). Plant species mediate changes in soil microbial $\mathrm{N}$ in response to elevated $\mathrm{CO}_{2}$. Ecology, 77, 2505-2515.

IPCC. (2007). In: Climate Change 2007: The Physical Science Basis. Contribution of Working Group I to the Fourth Assessment Report of the Intergovernmental Panel on Climate Change (eds Solomon, S., Qin, D., Manning, M., Chen, Z., Marquis, M., Averyt, K.B., Tignor, M. \& Miller, H.L.). Cambridge University Press, Cambridge, UK and New York, NY, 996 pp.

Jastrow, J.D., Miller, R.M., Matamala, R., Norby, R.J., Boutton, T.W., Rice, C.W. et al. (2005). Elevated atmospheric carbon dioxide increases soil carbon. Global Change Biol., 11, 2057-2064.

Jenkinson, D.S. \& Coleman, K. (2008). The turnover of organic carbon in subsoils Part 2. Modelling carbon turnover. Eur. J. Soil Sci., 59, 400-413.

Karnosky, D.F., Pregitzer, K.S., Zak, D.R., Kubiske, M.E., Hendrey, G.R., Weinstein, D. et al. (2005). Scaling ozone responses of forest trees to the ecosystem level in a changing climate. Plant Cell Environ., 28, 961-981.

Kasurinen, A., Kokko-Gonzales, P., Riikonen, J., Vapaavouri, E. \& Holopainen, T. (2004). Soil $\mathrm{CO}_{2}$ efflux of two silver birch clones exposed to elevated $\mathrm{CO}_{2}$ and $\mathrm{O}_{3}$ levels during three growing seasons. Global Change Biol., 10, 1654-1665.

van Kessel, C., Nitschelm, J., Horwarth, W.R., Harris, D., Walley, F., Lüscher, A. et al. (2000). Carbon-13 input and turn-over in a pasture soil exposed to long-term elevated atmospheric $\mathrm{CO}_{2}$. Global Change Biol., 6, 123-135.

van Kessel, C., Boots, B., de Graaff, M.-A., Harris, D., Blum, H. \& Six, J. (2006). Total soil $\mathrm{C}$ and $\mathrm{N}$ sequestration in a grassland following 10 years of free air $\mathrm{CO}_{2}$ enrichment. Global Change Biol., 12, 2187-2199.

King, J.S., Pregitzer, K.S., Zak, D.R., Sober, J., Isebrands, J.G., Dickson, R.E. et al. (2001). Fine-root biomass and fluxes of soil carbon in young stands of paper birch and trembling aspen as affect by elevated atmospheric $\mathrm{CO}_{2}$ and tropospheric $\mathrm{O}_{3}$. Oecologia, 128, 237-250.

King, J.S., Kubiske, M.E., Pregitzer, K.S., Hendrey, G.R., McDonald, E.P., Giardina, C.P. et al. (2005). Tropospheric $\mathrm{O}_{3}$ compromises net primary production in young stands of trembling aspen, paper birch and sugar maple in response to elevated atmospheric $\mathrm{CO}_{2}$. New Phytol., 168, 623-636.

Kubiske, M.E., Quinn, V.S., Marquardt, P.E. \& Karnosky, D.F. (2007). Effects of elevated atmospheric $\mathrm{CO}_{2}$ and/or $\mathrm{O}_{3}$ on intra- and interspecific competitive ability of aspen. Plant Biol., 9, 342-355.

Langley, J.A., McKinley, D.C., Wolf, A.A., Hungate, B.A., Drake, B.G. \& Megonigal, J.P. (2009). Priming depletes soil carbon and releases nitrogen in a scrub-oak ecosystem exposed to elevated $\mathrm{CO}_{2}$. Soil Biol. Biochem., 41, 54-60.

Larson, J.L., Zak, D.R. \& Sinsabaugh, R.L. (2002). Microbial activity beneath temperate trees growing under elevated $\mathrm{CO}_{2}$ and $\mathrm{O}_{3}$. Soil Sci. Soc. Am. J., 66, 1848-1856.

Leavitt, S.W., Paul, E.A., Kimball, B.A., Hendrey, G.R., Mauney, J.R., Rauschkolb, R. et al. (1994). Carbon isotope dynamics of free-air $\mathrm{CO}_{2}$-enriched cotton and soils. Agricult. For. Meteorol., 70, 81-101.

Leavitt, S.W., Pendall, E., Paul, E.A., Brooks, T., Kimball, B.A., Pinter, P.J. Jr et al. (2001). Stable-carbon isotopes and soil organic carbon in wheat under $\mathrm{CO}_{2}$ enrichment. New Phytol., 150, 305-314.

Lichter, J., Barron, S.H., Bevacqua, C.E., Finzi, A.C., Irving, K.F., Stemmler, E.A. et al. (2005). Soil carbon sequestration and turnover in a pine forest after six years of atmospheric $\mathrm{CO}_{2}$ enrichment. Ecology, 86, 1835-1847.

Liu, L., King, J.S. \& Giardina, C.P. (2005). Effects of elevated atmospheric $\mathrm{CO}_{2}$ and tropospheric $\mathrm{O}_{3}$ on leaf litter production and chemistry in trembling aspen and paper birch communities. Tree Phys., 25, 1511-1522.

Loya, W.M., Pregitzer, K.S., Karberg, N.J., King, J.S. \& Giardina, C.P. (2003). Reduction of soil carbon formation by tropospheric ozone under increased carbon dioxide levels. Nature, 425, 705707.

Luo, Y., Hui, D. \& Zhang, D. (2006). Elevated $\mathrm{CO}_{2}$ stimulates net accumulations of carbon and nitrogen in land ecosystems: a meta-analysis. Ecology, 87, 53-63.

Maie, N., Behrens, A., Knicker, H. \& Kögel-Knabner, I. (2003). Changes in the structure and protein binding ability of con- 
densed tannins during decomposition of fresh needles and leaves. Soil Biol. Biochem., 35, 577-589.

McMurtrie, R.E., Dewar, R.C., Medlyn, B.E. \& Jeffreys, M.P. (2000). Effects of elevated $\left[\mathrm{CO}_{2}\right]$ on forest growth and carbon storage: a modelling analysis of the consequences of changes in litter quality/quantity and root exudation. Plant Soil, 224, 135152.

Niklaus, P.A. \& Falloon, P. (2006). Estimating soil carbon sequestration under elevated $\mathrm{CO}_{2}$ by combining carbon isotope labelling with soil carbon cycle modelling. Global Change Biol., 12, 1909-1921.

Norby, R.J., Cotrufo, M.F., Ineson, P., O’Neill, E.G. \& Canadell, J.G. (2001). Elevated $\mathrm{CO}_{2}$, litter chemistry, and decomposition: a synthesis. Oecologia, 127, 153-165.

Parsons, W.F.J., Bockheim, J.G. \& Lindroth, R.L. (2008). Independent, interactive, and species-specific responses of leaf litter decomposition to elevated $\mathrm{CO}_{2}$ and $\mathrm{O}_{3}$ in a northern hardwood forest. Ecosystems, 11, 505-519.

Poorter, H. \& Navas, M.-L. (2003). Plant growth and competition at elevated $\mathrm{CO}_{2}$ : on winners, losers and functional groups. New Phytol., 157, 175-198.

Pregitzer, K., Loya, W., Kubiske, M. \& Zak, D. (2006). Soil respiration in northern forests exposed to elevated carbon dioxide and ozone. Oecologia, 148, 503-516.

Pregitzer, K., Burton, A., King, J. \& Zak, D. (2008). Soil respiration, root biomass, and root turnover following long-term exposure of northern forests to elevated atmospheric $\mathrm{CO}_{2}$ and tropospheric $\mathrm{O}_{3}$. New Phytol., 180, 153-161.

Ren, W., Tian, H., Chen, G., Liu, M., Zhang, C., Chappelka, A.H. et al. (2007). Influence of ozone pollution and climate variability on net primary productivity and carbon storage in China's grassland ecosystems from 1961 to 2000. Environ. Pollut., 149, 327-335.

Sitch, S., Cox, P.M., Collins, W.J. \& Huntingford, C. (2007). Indirect radiative forcing of climate change through ozone effects on the land-carbon sink. Nature, 448, 791-794.

Trueman, R.J. \& Gonzalez-Meler, M.A. (2005). Accelerated belowground $\mathrm{C}$ cycling in a managed agriforest ecosystem exposed to elevated carbon dioxide concentrations. Global Change Biol., 11, 1258-1271.

Trumbore, S. (2000). Age of soil organic matter and soil respiration: radiocarbon constraints on belowground $\mathrm{C}$ dynamics. Ecol. Appl., 10, 399-411.
Xie, Z., Cadisch, G., Edwards, G., Baggs, E.M. \& Blum, H. (2005). Carbon dynamics in a temperate grassland soil after 9 years exposure to elevated $\mathrm{CO}_{2}$ (Swiss FACE). Soil Biol. Biochem., 37, 1387-1395.

Zak, D.R., Holmes, W.E. \& Pregitzer, K.S. (2007). Atmospheric $\mathrm{CO}_{2}$ and $\mathrm{O}_{3}$ alter the flow of ${ }^{15} \mathrm{~N}$ in developing forest ecosystems. Ecology, 88, 2630-2639.

\section{SUPPORTING INFORMATION}

Additional Supporting Information may be found in the online version of this article:

Table S1 Bulk density, carbon concentration and pool size by year, treatment and community.

Table S2 ${ }^{13} \mathrm{C}$ mixing model inputs and old and new carbon pools

Table S3 ANOva $P$-values for the differences in isotopically new carbon and old soil carbon based on the results of three alternate mixing models for determining new soil C: (a) 50\% roots, 50\% leaf litter; (b) 25\% roots, $75 \%$ leaf litter; and (c) $75 \%$ roots, $25 \%$ leaf litter.

As a service to our authors and readers, this journal provides supporting information supplied by the authors. Such materials are peer-reviewed and may be re-organized for online delivery, but are not copy-edited or typeset. Technical support issues arising from supporting information (other than missing files) should be addressed to the authors.

Editor, David Hooper

Manuscript received 25 May 2009

First decision made 2 July 2009

Second decision made 27 July 2009

Manuscript accepted 6 August 2009 